\title{
TEN YEARS EXPERIENCE WITH JORGE LOBO'S DISEASE IN THE STATE OF ACRE, AMAZON REGION, BRAZIL
}

William John WOODS(1), Andréa de Faria Fernandes BELONE(2), Léia Borges CARNEIRO(1) \& Patrícia Sammarco ROSA(2)

\begin{abstract}
SUMMARY
Jorge Lobo's disease is a cutaneous and subcutaneous mycosis that affects patients in the Amazon region. The number of patients is relatively small, but the real situation of the disease as public health problem is not known, because Jorge Lobo's disease is not a notifiable disease. This study aims to report the clinical evolution in patients affected and to determine the prevalence and areas of occurrence of the disease. A retrospective study was carried out based on the analysis of the clinical records, which included a collection of photographs of patients in the Department of Sanitary Dermatology, in Rio Branco, and patients seen in the interior of the state. In a decade, in Rio Branco, 249 cases of the disease were reported, 30 were females and 219 males. Of these patients, 153 had localized lesions, 94 of them were on one ear, 55 had multifocal lesions and 41 had disseminated lesions. The average time between the onset of symptoms and diagnosis was 19 years. The average age at the time of diagnosis was 53 years, and ages ranged from 14 to 96 years.
\end{abstract}

KEYWORDS: Jorge Lobo's disease; Epidemiology; Prevalence; Lacazia loboi.

\section{INTRODUCTION}

Jorge Lobo's disease, also known as lobomycosis and lacaziosis, was described for the first time in 1931 by Jorge Oliveira Lobo, physician and professor of Dermatology from the School of Medicine of Recife, $\mathrm{PE}^{13}$. The patient, a 52 years-old male, had worked as a rubber cutter in the Amazon and had skin lesions resembling keloid scars. Between 1938 and 1962 there were 29 cases registered in Brazil, one in Costa Rica, two in Venezuela, and two in French Guiana ${ }^{11}$. BARUZZI et $a l .{ }^{2,4}$ reported numerous cases among Caiabi Indians living in an area between the rivers Teles Pires and Tapajós, in the North of the state of Mato Grosso. Interestingly, when these Indians were transferred to the Xingu Indigenous National Park, no new case arose in the tribe. This may indicate there was no source of contamination in the Xingu National Park. Other indigenous tribes that inhabit the North of Mato Grosso State, in Brazil, do not have the disease. The high incidence among Caiabi Indians indicates that besides the risk factors, it is likely that there is a genetic susceptibility that predisposes to Jorge Lobo's disease.

In Europe, one case was observed by SYMMERS ${ }^{31}$, the patient was an attendant who took care of a dolphin infected with the disease. BURNS et al. ${ }^{5}$ reported the first case in the United States in a man of 42 years from Georgia, which referred to the appearance of lesions on the skin, after a trip to Venezuela where he had done rappelling in Angel Falls in Canaima.
Some authors refer to constant increase in number of Jorge Lobo's disease cases. SILVA \& NEVES ${ }^{28}$ cited 252 cases in Brazil and 385 in the world. According to PRADINAUD \& TALHARI ${ }^{21}$, the statistics in 1996 was 418 cases worldwide. This remained unchanged until 1998, when the number of cases reported in Brazil was $255^{7}$. OPROMOLLA et al. ${ }^{17}$ estimated that 458 patients were diagnosed with the disease, of which 295 were in Brazil and 40 of these cases were in the state of Acre.

Jorge Lobo's disease is found, almost exclusively, in the tropical zone of the rainforest. The Brazilian Amazon valley has the climatic characteristics favoring the disease, tropical, hot and humid equatorial climate (Fig. 1). Until today, it is unclear which factors may act in the susceptibility and spread of the disease ${ }^{2}$. The transmission of Jorge Lobo's disease is probably by contact of the infectious material with skin solutions of continuity. Evidence suggests the skin as portal of entry of the fungus by the fact that the lesions are located almost exclusively in skin tissue.

The proven presence of dolphins with $L$. loboi indicates that the infective material must be present in seawater or freshwater. In 1971, MIGAKI et al. ${ }^{15}$ described the first case of the disease in dolphins, a specimen (Tursiops trucantus) caught on the West coast of Florida. A second case, also in Florida, was studied by WOODWARD ${ }^{35}$. DE VRIES \& LAARMAN ${ }^{8}$ described a new case in a dolphin (Sotalia guianensis) caught in the estuary of the river Surinam. In 1970, another dolphin was

(1) Departamento de Dermatologia Sanitária, Avenida Nações Unidas 700, Bosque, 60908-620 Rio Branco, Acre, Brasil

(2) Instituto Lauro de Souza Lima, Rodovia Cmte J.R. Barros, Km 225, 17034-971 Bauru, SP, Brasil.

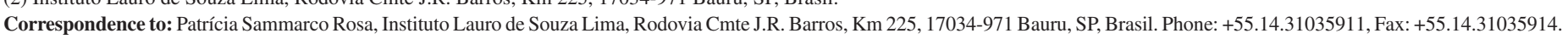
E-mail: prosa@ilsl.br 


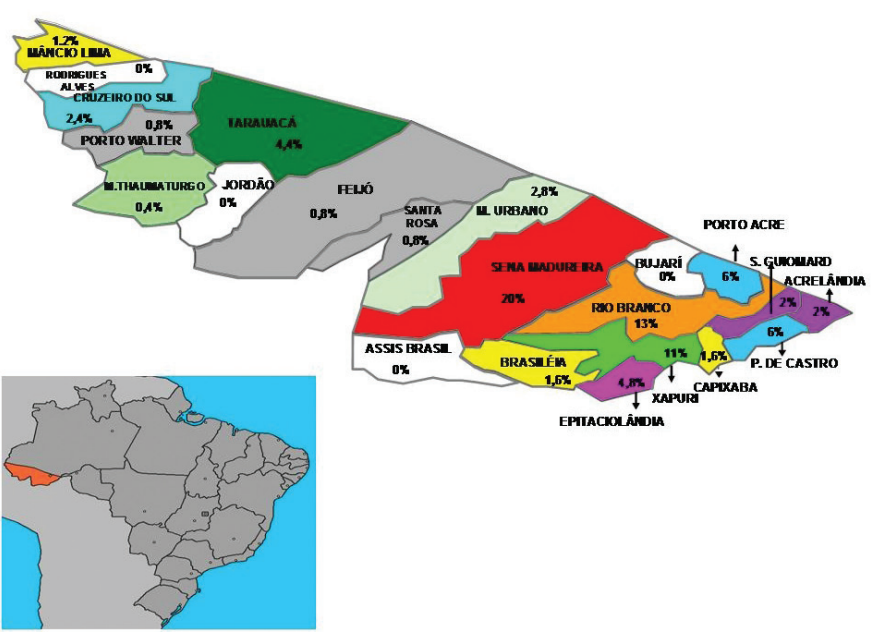

Fig. 1 - Percentage of Jorge Lobo's disease cases in the municipalities of Acre State. Insert: location of Acre State on North of Brazil. (State in red on West of the Brazilian map).

caught in the Bay of Biscay to the north of the Gulf of Biscay (Europe), with lesions of the disease, and was registered as the first case of the disease in dolphins caught in European waters ${ }^{31}$. Jules Sotos, coordinator of the museum of oceanography at the University of the Itajaí valley, in 2007 , reported the death of a dolphin, which ran aground on the central beach of the city Navegantes. The female dolphin had Jorge Lobo's disease, and presented with the body and the palate covered with sores, caused by this fungi ${ }^{30}$. For 15 years the biologist Marcos de Oliveira Santos has carried out research on the life and routine of dolphins that live near the shores of São Paulo State and near the shores of Northern Paraná, and more precisely in Cananéia, Paranaguá. In 2006 and 2007 he observed that these animals had marks on the skin. With the help of Marie-Francoise Van Bressen, a Dutch veterinary specialist, who works at the Center for Research of Cetaceans in Peru, identified the markings as Jorge Lobo's disease. The study was based on more than one hundred photographs ${ }^{32}$.

Jorge Lobo's disease affects mainly the subcutaneous tissues and skin, but the fungi can be present in regional lymph nodes ${ }^{20}$ and has been described in the testicle in an isolated case ${ }^{23}$. There are no reports of involvement of the general condition of the patients, except when there is extensive ulceration of the lesions with secondary infection ${ }^{25}$. When there are multiple large lesions, besides the deformity, the itching becomes unbearable ${ }^{34}$.

SILVA $^{25}$ and SILVA \& DE BRITO ${ }^{27}$ proposed a clinical classification based on the morphology of the lesions: infiltrative, keloid-like, in plaques, verruciform and ulcerated. According to BARUZZI \& $\mathrm{AZEVEDO}^{1}$ and LACAZ et al. ${ }^{11}$ to facilitate surgical excision, lesions were classified according to their distribution: 1) isolated or localized forms and 2) disseminated forms. According to OPROMOLLA et $a l .{ }^{17}$ the lesions can be classified as 1) isolated or localized forms, 2) disseminated forms and 3) multifocal forms (in one limb or section of the limb). In the chronic phase of the disease, it can be noted there is great polymorphism of the cutaneous lesions, with the presence of macules, papules, infiltrated plaques, nodules, often resembling keloids, gummy formation, besides the wart like lesions. The lesions in the lower limbs are often ulcerated ${ }^{11}$.
The etiologic agent of this disease, L. loboi, appears abundantly in skin lesions as round yeast-like cells, measuring 6 to $12 \mu \mathrm{m}$ in diameter, with a thick cell wall and cytoplasm with homogeneous or granular contents ${ }^{5,11}$. This fungus reproduces itself by simple budding, also presents catenulated forms with 3-6 cells together, forming a stem structure like in a rosary. Although the amount of fungi in parasitized tissue is large, many of the fungal cells are not viable ${ }^{11,19}$.

There were many attempts to find a cure for Jorge Lobo's disease but there have been few satisfactory results. The drugs and outcome of treatment schemes for the disease are demonstrated in Table 1.

The present study aimed to estimate the prevalence of Jorge Lobo's disease in the patients registered in the Outpatient Clinic of the Service of Dermatology of the Emergency Hospital in Rio Branco, in the state of Acre, from 1998 to 2008, and to better understand the factors that may relate to the infection of patients and risk factors involved in its transmission. We intend to analyze the time between the onset of symptoms and diagnosis and seek means of obtaining early diagnosis.

\section{METHOD}

The retrospective study was carried out based on the analysis of the clinical records of all patients who were attended at the Department of Sanitary Dermatology of Acre, between 1998 and 2008.

A collection of clinical pictures of patients was also accessed to evaluate evolution of the patients throughout treatment.

The data collected from each patient were: personal data; demographic data; history of the disease in relation to its manifestations and clinical evolution.

\section{RESULTS AND DISCUSSION}

Epidemiological data of Jorge Lobo's disease in the state of Acre: There were 249 Jorge Lobo's disease cases diagnosed in the Department of Dermatology of the Public Health Service between 1998 and 2008. Of these, 30 patients are females and 219 males. The average age at the time of diagnosis was 53 years, being the oldest patient 96 years-old and the youngest 14 years-old. The average time between the onset of symptoms and the time of diagnosis was 19 years; the longest time was 60 years and the shortest one year.

Early diagnosis of this disease is difficult. It could be observed that most patients sought health services only years after the onset of skin lesions, motivated either by increasing the size of the same, or by the appearance of new lesions. Among the patients studied in this work, the patient with the most recent onset of the disease presented an initial lesion, with evolution of one year in the lower lip, she was brought by her mother, who was already undergoing treatment.

DIAS et al. ${ }^{9}$ noted that the majority of cases described in the literature are isolated cases, without reference to the disease in other family members. In patients studied in the present work, we report a father with extensive lesions throughout his body and his son with extensive lesions on the right arm. Also, the mother referred to above presented extensive lesions on the lower limbs and her daughter a single lesion on the lower 
WOODS, W.J.; BELONE, A.F.F.; CARNEIRO, L.B. \& ROSA, P.S. - Ten years experience with Jorge Lobo's disease in the State of Acre, Amazon region, Brazil. Rev. Inst. Med. Trop. Sao Paulo, 52(5): 273-8, 2010.

Table 1

Therapeutic results in Jorge Lobo's disease

\begin{tabular}{|c|c|c|}
\hline AUTHOR & DRUGS USED & RESULTS \\
\hline REYES et al. $1960^{22}$ & $\begin{array}{l}\text { Sulfadimetoxine } \\
1000 \mathrm{mg} / \text { day }\end{array}$ & Improvement of the infiltrations \\
\hline SILVERIE et al., $1963^{29}$ & Sulfametoxipiridazine $500 \mathrm{mg} /$ day & Reduction of the nodules \\
\hline LONDOÑO, $1968^{14}$ & Anfotericin B infiltration & Unsatisfactory \\
\hline BARUZZI \& AZEVEDO, $1991^{1}$ & $\begin{array}{l}\text { Clofazimine, } 2 \text { years } \\
100 \text { a } 200 \mathrm{mg} / \text { day }\end{array}$ & Unsatisfactory \\
\hline SILVA, $1978^{26}$ & $\begin{array}{l}\text { Clofazimine } 3 \text { to } 6 \text { months } \\
200 \mathrm{mg} / \text { day }\end{array}$ & Slight reduction of lesions \\
\hline TALHARI et al., $1981^{32}$ & $\begin{array}{l}\text { Clofazimine } 6 \text { months to } 3 \text { years } \\
200 \mathrm{mg} / \text { day } \& \text { electrocoagulation }\end{array}$ & $\begin{array}{l}\text { Decreased number of fungi } \\
\text { Some regression of lesions }\end{array}$ \\
\hline CUCÊ et al., $1980^{6}$ & Ketaconazole 90 days 400 mg/day & $\begin{array}{l}\text { Decreased number of fungi } \\
\text { Some regression of lesions }\end{array}$ \\
\hline BARUZZI et al., $1980^{3}$ & Ketaconazole 400 mg/day & Moderate improvement \\
\hline LAWRENCE \& AJELLO, $1986^{12}$ & $\begin{array}{l}\text { Ketaconazole } 6 \text { months } \\
200 \mathrm{mg} / \text { day }\end{array}$ & Unsatisfactory \\
\hline OPROMOLLA, $1996^{16}$ & $\begin{array}{l}\text { Itraconazole } 6 \text { months } \\
100 \text { to } 200 \mathrm{mg} / \text { day }\end{array}$ & Unsatisfactory \\
\hline PRADINAUD \& TALHARI, $1996^{21}$ & $\begin{array}{l}\text { Fluorcitosine, } 50 \text { days } \\
100 \mathrm{mg} / \mathrm{kg}\end{array}$ & Unsatisfactory \\
\hline OPROMOLLA, $2000^{18}$ & $\begin{array}{l}\text { Anfotericin B, DDS, Fluorcitosine Terbinafine and } \\
\text { Clofazimine }\end{array}$ & Softening of the lesions \\
\hline OPROMOLLA $2000^{18}$ & $\begin{array}{l}\text { Clofazimine, DDS, } \\
\text { Fluorcitosine and Itraconazole }\end{array}$ & Decreased viability \\
\hline FISCHER et al., $2002^{10}$ & $\begin{array}{l}\text { Itraconazole and Clofazimine } \\
100 \mathrm{mg} / \mathrm{kg}\end{array}$ & Clinical cure \\
\hline ROSA et al. $2009^{24}$ & $\begin{array}{l}\text { Itraconazole, Clofazimine, DDS } \\
\text { Surgical excision }\end{array}$ & Clinical cure \\
\hline
\end{tabular}

DDS $=$ dapsone

lip. Since these four patients all lived in interior of the forest, there is no recorded evidence of transmission from one person to another, it is most likely that they became contaminated individually from an environmental source of the fungi.

LACAZ et al. ${ }^{11}$ indicate that no particular ethnic group has a greater susceptibility to acquire $L$. loboi and described the disease in white, blacks and Indians. However, the results of the present study show that there are very few Caucasians presenting Jorge Lobo's disease in the state of the Acre, however, this could be a bias, because most of the population in Acre, with or without the disease, has dark skin.

LACAZ et al. ${ }^{11}$ also reported that the disease affects mainly rubber cutters, miners, i. e., people who are in direct contact with the tropical forest. Similarly, all the patients in the present study worked or lived in the interior of the rain forest or on the banks of the rivers when the first symptoms appeared. Table 2 shows the distribution according to the municipality where the patients first appeared with symptoms of Jorge Lobo's disease. There were no patients coming from the municipalities of Bujari, Assis Brasil, Jordan or Rodrigues Alves showing symptoms of the disease. Patients of the municipalities of Sena Madureira, Rio Branco, Xapuri, Plácido de Castro, Porto Acre and Epitaciolândia (municipalities with the highest numbers of cases), have easy access to the clinical center of the Dermatology Department in Rio Branco. Most of the other patients were seen when the medical doctor in the present work and his team traveled within these municipalities working with the Program for Elimination of Leprosy. We observed that among all patients who acquired the disease in the municipality of Sena Madureira, 14 of them lived on the banks of the Antimari River at the time, which is an endemic area for Jorge Lobo's disease. Fig. 1 shows the distribution of Jorge Lobo's Disease in the municipalities of the Acre, a state with a population of 691,169 inhabitants, with 4.5 inhabitants $/ \mathrm{km}^{2}$-population density and altitude of $153 \mathrm{~m}$ above sea level in the capital, Rio Branco.

The river Purus and its tributaries pass through the municipalities of Sena Madureira, Manoel Urbano, Santa Rosa, Rio Branco, Xapuri, Brasiléia, Epitaciolândia and Boca do Acre in the state of Amazonas. Among the eight patients in the state of Amazonas, six are from Boca do 
WOODS, W.J.; BELONE, A.F.F.; CARNEIRO, L.B. \& ROSA, P.S. - Ten years experience with Jorge Lobo's disease in the State of Acre, Amazon region, Brazil. Rev. Inst. Med. Trop. Sao Paulo, 52(5): 273-8, 2010.

Table 2

Distribution of Jorge Lobo's disease cases diagnosed in the State of Acre between 1998 and 2008, divided by municipality where patients lived when the first symptoms of the disease appeared

\begin{tabular}{|c|c|}
\hline Municipality & Number of cases \\
\hline Sena Madureira & 83 \\
\hline Rio Branco & 33 \\
\hline Xapuri & 28 \\
\hline Plácido de Castro & 16 \\
\hline Porto Acre & 15 \\
\hline Epitaciolandia & 12 \\
\hline Tarauacá & 11 \\
\hline Manoel Urbano & 7 \\
\hline Cruzeiro do Sul & 6 \\
\hline Senador Guiomar & 5 \\
\hline Acrelandia & 5 \\
\hline Brasileia & 4 \\
\hline Capixaba & 4 \\
\hline Mancio Lima & 3 \\
\hline Porto Walter & 2 \\
\hline Feijó & 2 \\
\hline Santa Rosa & 2 \\
\hline Marechal Taumaturgo & 1 \\
\hline Amazonas State * & 8 \\
\hline Rondonia State * & 2 \\
\hline Total & 249 \\
\hline
\end{tabular}

* Treated in the Department of Dermatology in Rio Branco.

Acre. This indicates that the Purus River and its tributaries, which include the river Antimari, are the largest endemic areas of Jorge Lobo's disease in Acre. We believe that the valley of the river Juruá, a region that was not thoroughly studied, must have a hidden prevalence of the disease.

Clinical aspects: Among the 249 patients in this study, 153 had localized lesions, 94 of them had lesions in one ear, of these 38 had lesions in the right ear and 56 in the left ear. None of the patients had lesions in both ears, but three patients had lesions in one ear and in another region of the body. This suggests multiple inoculation sites, as previously stated by OPROMOLLA et al. $^{20}$. From the total number of cases, 55 had multifocal lesions and 41 had disseminated lesions (Fig. 2a, b, c, d).

Lesions were observed in the right upper limb in 34 patients and in the left in 36 patients. Seven patients had lesions on both upper limbs. In the lower limb, 20 patients had lesions on the right member and 34 on the left, four patients had lesions on both lower limbs and eight patients had lesions on the face. Another eight patients had lesions on the abdomen and six on the back. Two patients had lesions on the buttocks and one on the right (female) breast.

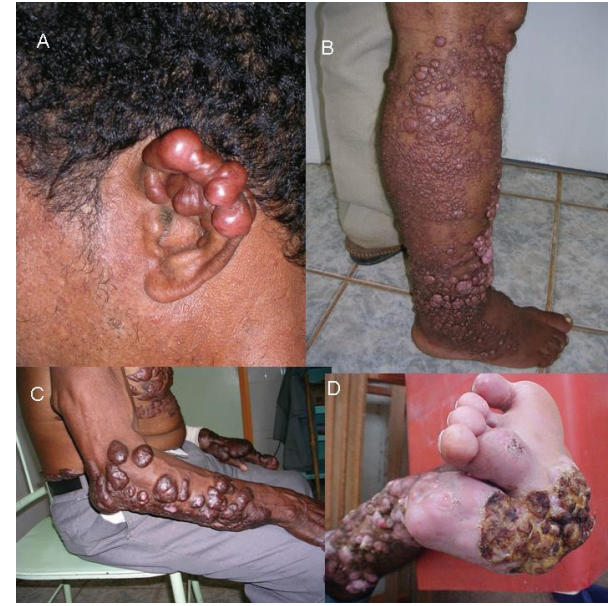

Fig. 2 - Characteristic clinical forms of Jorge Lobo's disease. A. Isolated form; B. Multifocal form on lower limb; C. Extensive disseminated form; D. Ulcerated form on leg and foot.

We draw attention to the fact that the left side of the body is the most affected. A possible explanation for this is that rubber cutters going through the forest carry the cutlass in his right hand and use their left hand or foot to push clear the bushes they have cut, making the left side more vulnerable to trauma through where fungi probably penetrate the skin.

Lesions may appear at any anatomic site, but there are no reports of lesions affecting the mucous membranes. Despite two patients with ulcerated lesions developing squamous cell carcinoma, the general health of the patient is good. The local symptom is intensive itching. When there are extensive lesions disseminated over a large area, beside the deformity they cause, the itching becomes unbearable. Ulceration is usually secondary to trauma because of itching.

Treatment of Jorge Lobo's disease in Acre: Because of the lack of an effective medical treatment, in Acre, since 1979, patients have been submitted to surgeries to remove lesions, which improved substantially their quality of life. However, many of them presented recurrence of the symptoms after variable periods post surgery.

Over thirty years of experience working in the Leprosy Elimination Program of Acre, also following the guidelines of the distinguished Dr. Diltor OPROMOLLA ${ }^{18}$ (dapsone and clofazimine) and of the esteemed professor of Dermatology, Sinésio TALHARI et al. ${ }^{32}$ (clofazimine 200 $\mathrm{mg} / 6$ months), the authors of the present work have used various forms of treatment for Jorge Lobo's disease, all of them without very promising results ${ }^{17}$.

From the total number of patients in Acre, 10 patients who had also been treated for leprosy demonstrated the best results of treatment. One of these patients, a female patient from the interior of the state finished her treatment for multibacillary leprosy, (rifampicin, clofazimine and dapsone), begged not to suspend the treatment because the Jorge Lobo's disease lesions were softening and the itching was decreasing. During follow-up of the leprosy patients treated for multibacillary leprosy, who also had Jorge Lobo's disease, we observed diminished itching caused by Jorge Lobo's disease; the lesion showed mild atrophy and when the lesion was surgically removed, there was no recurrence. These patients were periodically examined, considering the clinical evolution and laboratorial 
WOODS, W.J.; BELONE, A.F.F.; CARNEIRO, L.B. \& ROSA, P.S. - Ten years experience with Jorge Lobo's disease in the State of Acre, Amazon region, Brazil. Rev. Inst. Med. Trop. Sao Paulo, 52(5): 273-8, 2010.

examinations (biopsy and viability determination of the fungi collected from skin lesions) to document the improvement.

\section{CONCLUSION}

The prevalence of Jorge Lobo's disease in the state of Acre is not very high, 3.05/10,000 inhabitants, but the deformity and decreased productivity at work create a social burden for the carriers of this disease. We call attention to the fact that $96 \%$ of the patients are in the macro region of the valleys of the rivers Purus and Acre, where it is relatively easy to access the clinic of the Department of Sanitary Dermatology in Rio Branco. In the macro region of the river Juruá there is no health service available and there must be a hidden prevalence in this area. Nobody knows the true prevalence of this disease, which does not require compulsory notification.

It was an interesting coincidence to find patients who have Jorge Lobo's disease and are treated for multibacillary leprosy who showed great improvement of the lesions of Jorge Lobo's disease, some no longer with viable fungi. Perhaps this treatment could be the starting point for further search for a cure for Jorge Lobo's disease.

\section{RESUMO}

\section{Dez anos de experiência com a Doença de Jorge Lobo no estado do Acre, região amazônica, Brasil}

A doença de Jorge Lobo é micose cutânea e subcutânea que afeta pessoas na região Amazônica. O número de pacientes é relativamente pequeno, no entanto, a real prevalência da doença como problema de saúde pública é pouco conhecida. A doença de Jorge Lobo não é de notificação compulsória. Este estudo teve como objetivo determinar a prevalência, as áreas de ocorrência da doença de Jorge Lobo, além de sua evolução clínica. Um estudo retrospectivo foi desenvolvido com base na análise de prontuários de pacientes, incluindo documentação fotográfica dos mesmos, que foram atendidos no Departamento de Dermatologia Sanitária em Rio Branco e no interior do Estado. Foram registrados 249 casos em uma década em Rio Branco, 30 mulheres e 219 homens. Do total 153 apresentavam lesões localizadas, 94 lesões em apenas uma orelha, 55 lesões multifocais e 41 lesões disseminadas. A média de tempo entre o início dos sintomas e o diagnóstico foi de 19 anos. A média de idade no momento do diagnóstico foi de 53 anos, e as idades variaram de 14 a 96 anos.

\section{ACKNOWLEDGEMENTS}

The author would like to thank the Health professionals at Departamento de Dermatologia Sanitária in Rio Branco, Acre, for their help in assistance to the patients and the LACEN Laboratory of Rio Branco, Acre, for providing resources for sample processing and viability determination of Lacazia loboi.

\section{AUTHORS CONTRIBUTIONS}

WJW, AFFB and PSR contributed to the study concept and drafting of the manuscript. WJW and LBC were responsible for patients' management. AFFB and PSR were responsible for the complementary exams, histopathology and viability determination. All authors undertook the medical literature search, read and approved the final manuscript.

\section{REFERENCES}

1. Baruzzi RG, Azevedo RA. Doença de Jorge Lobo. In: Meira DA. Clínica de doenças tropicais e infecciosas. Rio de Janeiro: Interlivros; 1991. p. 299-306.

2. Baruzzi RG, Lacaz CS, De Souza FA. A história natural da doença de Jorge Lobo Ocorrência entre índios Caiabi (Brasil Central). Rev Inst. Med Trop Sao Paulo $1979 ; 21: 303-38$

3. Baruzzi RG, Marcopito LF, Pascalicchio FV. Emprego do ketoconazole no tratamento da doença de Jorge Lobo. In: $16^{\circ}$ Congresso da Sociedade Brasileira de Medicina Tropical; 1980; Natal, RN. Resumos. n³ 350.

4. Baruzzi RG, Castro RM, D'Andretta Jr C, Carvalhal S, Ramos OL, Ponrtes PL. Occurrence of Lobo's blastomycosis among "Caiabi" Brazilian indians. Int J Dermatol 1973;12:95-9.

5. Burns RA, Roy JS, Woods C, Padhye AA, Warnock D. Report of the first human case of lobomycosis in the United States. J Clin Microbiol. 2000;38:1283-5.

6. Cucê LC, Wroclawski EL, Sampaio SAP. Treatment of paracoccidioidomycosis, candidiasis, chromomycosis, lobomycosis and mycetoma with ketoconazole. Int J Dermatol. 1980;19:405-8.

7. De Brito AC, Quaresma JAS. Lacaziose: revisão e atualização. An Bras Dermatol. 2007;82: 461-71.

8. De Vries GA, Laarman JJ. A case of Lobo's disease in the dolphin Sotalia guianensis. J Aquat Mammals. 1973;1:26-33

9. Dias LB, Sampaio MM, Silva D. Jorge Lobo's disease. Observations on its epidemiology and some unusual morphological forms of the fungus. Rev Inst Med Trop Sao Paulo. $1970 ; 12: 8-15$

10. Fischer M, Chrusciak-Talhari A, Reinel D, Talhari S. Successful treatment with clofazimine and itraconazole in a 4 year-old patient after 32 years duration of disease. Hautarzt. 2002;53:677-81

11. Lacaz CS, Baruzzi RG, Rosa, MCB. Doença de Jorge Lobo. São Paulo: Editora da USP/ IPSIS; 1986.

12. Lawrence DN, Ajello L. Lobomycosis in Western Brazil: report of a clinical trial with ketoconazole. Am J Trop Med Hyg. 1986;35:162-66.

13. Lobo J. Um caso de blastomicose, produzido por uma espécie nova, encontrado em Recife. Rev Méd Pernambuco. 1931;1:763-75.

14. Londoño F. Blastomicose queloidiana. A propósito de um caso tratado com anfotericina B. Med Cutânea. 1968;2:521-4

15. Migaki G, Valério VA, Irvine B, Garner MR. Lobo's disease in an Atlantic bottle-nosed dolphin. J Am Vet Med Assoc. 1971;159:578-82.

16. Opromolla DVA. Experimentação terapêutica com o itraconazol na lobomicose. In: $51^{\circ}$ Congresso Brasileiro de Dermatologia; 1996; Recife, PE. Resumos.

17. Opromolla DVA, Taborda PRO, Taborda VBA, Viana S, Furtado JF. Lobomicose: relato de 40 casos novos. An. Bras Dermatol. 1999;74:135-41.

18. Opromolla DVA. Estudos terapêuticos na doença de Jorge Lobo. In: $55^{\circ}$ Congresso Brasileiro de Dermatologia; 2000; Salvador, BA. Resumos.

19. Opromolla DVA, Belone AFF, Taborda PRO, Taborda VBA. Correlação clinico-patológica em 40 casos novos de lobomicose. An. Bras. Dermatol., 2000;75:425-34.

20. Opromolla DVA, Belone AFF, Taborda PR, Rosa PS. Lymph node involvement in Jorge Lobo's disease: report of two cases. Int J Dermatol. 2003;42:938-41. 
21. Pradinaud R, Talhari S. Lobomycose. In: Encyclopedie Medico Chirurgicale, Maladies Infectieuses. Paris: Elsevier; 1996. 8-608-A-10:1-6.

22. Reyes O, Goihman M, Goldstein C. Blastomicosis queloidiana o enfermidad de Jorge Lobo. Dermatol Venez. 1960;2:245-55.

23. Rodriguez-Toro G. Lobomycosis. Int J Dermatol. 1993;32:324-32.

24. Rosa PS, Soares CT, Belone AFF, Vilela R, Ura S, Cury-Filho M, et al. Accidental Jorge Lobo's disease in a worker dealing with Lacazia loboi infected mice: a case report. J Med Case Reports. 2009;3:1-5.

25. Silva D. Micose de Lobo. Rev Soc Bras Med Trop. 1972;6:85-98.

26. Silva, D. Traitement de la maladie de Jorge Lobo par la clofazimine (B663). Bull Soc Path Exot., 1978;71:409-12.

27. Silva D, De Brito A. Formas clínicas não usuais de micose de Lobo. An Bras Dermatol. 1994;69:133-6.

28. Silva D, Neves C. Dois casos novos de micose de Lobo: atualização estatística. An Bras Dermatol. 1995;70:127-9.

29. Silverie R, Ravisse P, Vilar JP, Moulins C. La blastomycose chéloidienne ou maladie de Jorge Lobo en Guyane Française. Bull Soc Path Exot. 1963;56:29-35.
30. Sotos J. Golfinho fêmea morre de doença rara. Available from: http://www.golfinhos.net/ en/portal/noticias/202. Accessed: November 4, 2007

31. Symmers WC. A possible case of Lobo's disease acquired in Europe from a bottle-nosed dolphin (Tursiops truncates). Bull Soc Path Exot. 1983;76:777-84.

32. Talhari S, Cunha MGS, Barros MLB, Gadelha AR. Doença de Jorge Lobo. Estudo de 22 casos novos. Med Cutan Ibero Lat Am. 1981;9:87-96.

33. Van Bressem MF, Santos MC, Oshima JE. Skin diseases in Guiana dolphins (Sotalia guianensis) from the Paranaguá estuary, Brazil: a possible indicator of a compromised marine environment. Mar Environ Res. 2009;67(2):63-8.

34. Woods WJ, Belone AFF, Rosa PS, Ura S. Lobomicose, tratamento com poliquimioterapia multibacilar (PQT/MB). In: Simpósio Nacional de Micologia Médica: Cromoblastomicose, Lobomicose, Paracoccidiodomicose e Criptococose; 2005; Belém, PA. Anais.

35. Woodard JC. Electron microscopic study of lobomycosis (Loboa loboi). Lab Invest. 1972;27:606-12.

Received: 24 July 2009

Accepted: 8 July 2010 